\title{
Growth, distribution and physiochemical properties of wax apple (Syzygium samarangense): A Review
}

\author{
Mohammad Moneruzzaman Khandaker ${ }^{1^{*}}$ and Amru Nasrulhaq Boyce ${ }^{2}$ \\ ${ }^{1}$ School of Agriculture Science and Biotechnology, Faculty of Bioresources and Food Industry, Universiti Sultan \\ Zainal Abidin, Tembila Campus, 22200 Besut, Terengganu, Malaysia \\ ${ }^{2}$ Institute of Biological Sciences, Faculty of Science, University of Malaya, 50603, Kuala Lumpur, Malaysia
}

*Correspondence: moneruzzaman@unisza.edu.my

\begin{abstract}
There is increasing concern about the fruit growth, development and quality of wax apple (Syzygium samarangense), a widely cultivated fruit tree in South East Asia. The growth and development of this fruit is sometimes very low due to low photosynthates supply at early growth stages. Growth regulators, hydrogen peroxide and phloemic stress are important tools to improve the growth, development and quality of horticultural products. The extracts of wax fruits, flower and bark have potent free radical scavenging, antioxidation, antimutation and anticancer activities. The leaves of wax apple used as tea and is proposed as a possible supplement for type II diabetes patients. Wax apple studied for its numerous pharmacological properties such as antioxidant and antidiabetic properties, anti-inflammation and antinociceptive activity, wound healing activity, antiulcerogenic effect, antibacterial, anticancer and also it's potential as an uterotonic agent. From this review, it can be concluded that $\mathrm{GA}_{3}, \mathrm{NAA}, 2,4-\mathrm{D}, \mathrm{H}_{2} \mathrm{O}_{2}$ and girdling have significant effect on fruit growth, development and yield improvement. Fruit pigmentations and anthocyanin content also significantly by using these growth promoting chemicals and girdling technique. This review paper provide detail information about wax apple fruit growth and development, origin, ecology, fruit morphology and variety, commercial usage, quality improvement and its medicinal benefits.
\end{abstract}

Keywords: Distribution, growth, morphology, plant, quality, wax apple.

\section{Introduction}

The wax apple is a tropical fruit which belongs to the genus Syzygium in the family Myrtaceae and is fairly widely cultivated and grown throughout Malaysia mainly as smallholdings ranging from 1 to 5 ha with its hectare age estimated at 1,500 ha in 2005 (Zen-hong et al., 2006). Malaysian climate is suitable for the wax apple production and the fruit can be harvest all year-round (Khandaker et al., 2011). It has become an increasingly popular fruit in the tropical region where it can fetch a price of up to 3USD per kilogram and has the potential to bring great benefit to local farmers and the country's economy (Khandaker et al, 2012). There is a great scope to develop wax apple fruit industry in Malaysia and other tropical countries. It has been well documented that the quality of the fruits can be affected by certain horticultural cultural practices, such as the application of plant growth hormones (Guardiola, 1992).

In Malaysia, there are three species which bear edible fruits, namely, the water apple (Syzygium aqueum), malay apple (Syzygium malaccense) and wax apple (Syzygium samarangense). Wax apple is the most popular of the three in Southeast Asia and produces red, pink and green fleshy fruits. The fruits are eaten raw with salt or cooked as a sauce which has thirst-relieving properties. The fruit is oblong, pear shaped and $5-12 \mathrm{~cm}$ in length, with four fleshy calyx lobes and 1- 4 seeds (1-2 cm in diameter) (Fig. 1). Among the three edible cultivars of wax apple, 'Masam manis pink' and 'Jambu madu red' cultivar are comparatively better than
'Giant green' cultivar under South Asian conditions (Moneruzzaman et al., 2011).

Myrtaceae plants are mostly used as medicinal plants for the treatment of bronchitis, asthma, diabetes mellitus and inflammation syndromes (Gurib-Fakin, 2006). In addition, the plants extracts have potent free radical scavenging, antioxidation, antimutation and anticancer activities (Neergheen et al., 2006). The wax apple leaves contain ellagitannins, flavanones, flavonol glycosides, proanthocyanidins, anthocyanidins, triterpenoids, chalcones and volatile terpenoids. The volatile oils from leaves of Syzygium species contain a high percentage of terpenoids and $\gamma$-terpinene with tannins and related compounds (Wong and Lai, 1996). It has been reported that ethanolic and hexane extracts of these leaves exhibited immunostimulant activity and relax the hyper motility of the gut while the alcoholic extract of the bark showed antibacterial activity (Srivastava and Shaw, 1995; Ghayur et al., 2006). The flowers are astringent and are believed to play a role in halting diarrhoea and show antibiotic action against Staphylococcus aureus, Mycobacterium smegmatis and Candida albicans (Zen-hong et al., 2006).

The fruit pulp of wax apple is a rich source of phenols, flavonoids and several antioxidant compounds and as a result it is believed to have great potential benefits for human health and used in traditional medicine to cure diabetes. Resurreccion-Magno et al. (2005) reported that wax apple fruit extract showed antihyperglycemic activity in allxan- 
induced (Type $1 \mathrm{DM}$ ) diabetic of mice. The leaves and seeds of wax apple have been shown to have antimicrobial activities against Pseudomonas aeruginosa, Klebsiella pneumonia and Cryptococcus neoformans (Srivastava and Shaw, 1995). Several syzygium species were reported to possess antibacterial, antifungal and anti-inflammatory activities (Chandrasekaran and Vankatesalu, 2004; Shafi et al., 2002). The flavonoids, isolated from wax apple, were reported to possess antihyperglycemic activity, spasmolytic and immunomodulatory activity (Resurreccion-Magno et al. 2005; Amor et al., 2005; Kuo et al., 2004). In Malaysia, the powdered dried leaves are used to treat a cracked tongue and a preparation from the root is used to relieve itching and to reduce swelling. Currently, there is scarcity of information about the growth, distribution and physiochemical properties of wax apple. The aim of this review is to provide a details report on cultivation, ecology, fruit growth and development, quality improvement, and potential benefits of pharmaceutical value of wax apple fruits.

\section{Botany of wax apple}

The tree is commonly cultivated throughout the tropical lowlands in South East Asia where it is believed to originate from. The genus Syzygium consists of about 1100 tropical species. The nomenclature of the jambu air fruits is as follows (Morton, 1987): Kingdom: Plantae, Sub Kingdom: Tracheobionta (Vascular plants), Super Division: Spermatophyta (Seed plants) Division: Magnoliophyta (Flowering plants), Class: Magnoliopsida (Dicotyledons), Order: Myrtales, Family: Myrtaceae, Genus: Syzygium, Species: Syzygium samaragense (Blume) Merr. \& Perry. Common names of $S$. samarangense include wax jambu, wax apple, java apple (English); jambu semarang, jambu klampok (Indonesian); jambu air mawar (Malay); makopa (Filipino); chomphu-kaemmaem, chomphu-khieo (Thai); roi (Vietnamese); bellfruit (In Taiwan) (Verheij and Coronel, 1991). Moneruzzaman et al. (2012a) reported that the different cultivars of wax apple varied markedly with respect to their morphological and physiological characteristics and that appeared to be due to their genetic differences.

\section{Ecology and distribution of wax apple}

The fruit tree, although almost completely unknown outside Southeastern Asia, is an economically important fruit crop in Taiwan (Shu et al., 1996). The 'Pink' ('Nun-Young' in Chinese) cultivar represents $99 \%$ of the planted area in Taiwan (Wang, 1991). The regular blooming time for 'Pink' is around March in Taiwan (Young, 1951). However, 'Pink' blooms and sets fruit almost year-round after flowering (Shu et al., 1996; Wang, 1991). As a result, fruits at different growing stages could be found in different orchards, different trees and even on the same tree. Located at the center of origin, Indonesia has a huge amount of variety with great diversity. Pale Green, Dark Red, Light red and Green are the four major Indonesian varieties. Fruit production is non seasonal, however the peak periods are in March to April and November to December. The major wax apple cultivars in Thailand are Phet Jin Da, Number one, Phet Sam Phran, Dang Indo, Phet Nam Pueng, Thub thim chan. Fruits can be harvested all the year round. Despite its name, this cultivar produces fruits varying from pink to deep red, depending on environmental and cultural conditions (Shu et al., 2001). It has been also reported that the photosynthetic yield had a strong correlation with the fruit biomass among the three cultivars. Jambu madu Red and Masam manis pink cultivars are comparatively better than 'Giant Green' cultivar if cultivated under South Asian conditions (Adel et al., 2001). Wax apple grows best in areas with a fairly long dry season. This does not mean that this species is drought-resistant.

The species require a reliable water supply and are often planted along streams or ponds. Current distribution ranges from India through South-East Asia to the Pacific Islands (the Malay apple features in Fijian mythology). S. samarangense is the most popular among the three species grown in SouthEast Asia (Fig. 2) (Chang et al., 2003). Now, the tree is cultivated throughout the tropics as far as east of Hawaii, as well as Central and South America (Whistler and Craig, 2006) (Fig. 2). Recently, wax apple has become a popular exotic fruit in western countries because the combination of apple-like crispness, watery sweet and low-acid taste and the aroma of roses (FAO, 2005).

Presently, wax apple cultivation also spread in Indonesian island of Java, Philippines, Thailand and other Southeast Asian countries (Fig. 2). China's Guangdong, Hainan, Fujian, Guangxi, Yunnan and Sichuan provinces (autonomous regions) has a small area of cultivation. Cultivation in Taiwan, the largest species of its greatest economic value for the black pearl wax apples and black diamond wax apple.

\section{Growth and flowering of trees}

The trees of S. samaragense are cultivated in home gardens, often planted along driveways and paths as well as cultivated in small holdings. The trees grow well in fairly moist tropical lowland areas up to $1200 \mathrm{~m}$ in elevation. They also grow best in areas with a fairly long dry season (Nakasone and Paul, 1998). However this does not mean that the tree is droughtresistant. In fact it requires a reliable supply of water and is often planted along small rivers, streams or ponds (Hakim and Panggabean, 1992). The tree is 3-15 m tall, with short and crooked trunk, $25-50 \mathrm{~cm}$ diameter, often branched near the base and with wide, irregular canopy. Leaves are opposite, elliptic to elliptic-oblong, $10-25 \mathrm{~cm} \times 5-12 \mathrm{~cm}$, coriaceous with thin margin, pellucid dotted, rather strongly aromatic when bruised; petiole thick, 3-5 mm long. The wax apple is a heavy producer on well fertilized good soils, and can produced more than 200 clusters per tree, with 4-5 fruits in each cluster at maturity. Wax apple commonly flowers early or late in the dry season; the flowers appear to be selfcompatible and the fruit ripens 40-50 days after anthesis. Inflorescences are terminal and in axils of fallen leaves, 3-30flowered; flowers $3-4 \mathrm{~cm}$ in diameter, calyx-tube ca. $1.5 \mathrm{~cm}$ long, ventricose at apex, lobes 3-5 mm long; petals 4, orbicular to spathulate, $10-15 \mathrm{~mm}$ long, yellow-white; stamens numerous, up to $3 \mathrm{~cm}$ long; style up to $3 \mathrm{~cm}$ long (Fig. 1, Fig. $3 \& 4$ ).

\section{Fruit growth}

Fruit is a berry, pear shaped, broadly pyriform, crowned by the fleshy calyx with incurved lobes, $3.5-5.5 \mathrm{~cm} \times 4.5-5.5$ $\mathrm{cm}$, light red to white; fruit flesh is white spongy, juicy, aromatic, sweet-sour in taste (Fig.1). Seeds 0-2, mostly suppressed, globose, up to $8 \mathrm{~mm}$ in diameter (Morton, 1987). The waxy fruits are peer shaped and the color of the fruits is usually pink, light red, red, sometime time green or creamcolored (Morton, 1987). In Malaysia, jambu madu fruit fruits are eaten with salt or cooked as a sauce. Fruit production is non seasonal and fruits can be harvest three times per year. Almost all of the fruit is edible. It has been reported that growth and flowering of wax apple can be regulated by $\mathrm{GA}_{3}$ and NAA application (Khandaker et al., 2011\& Khandaker et 


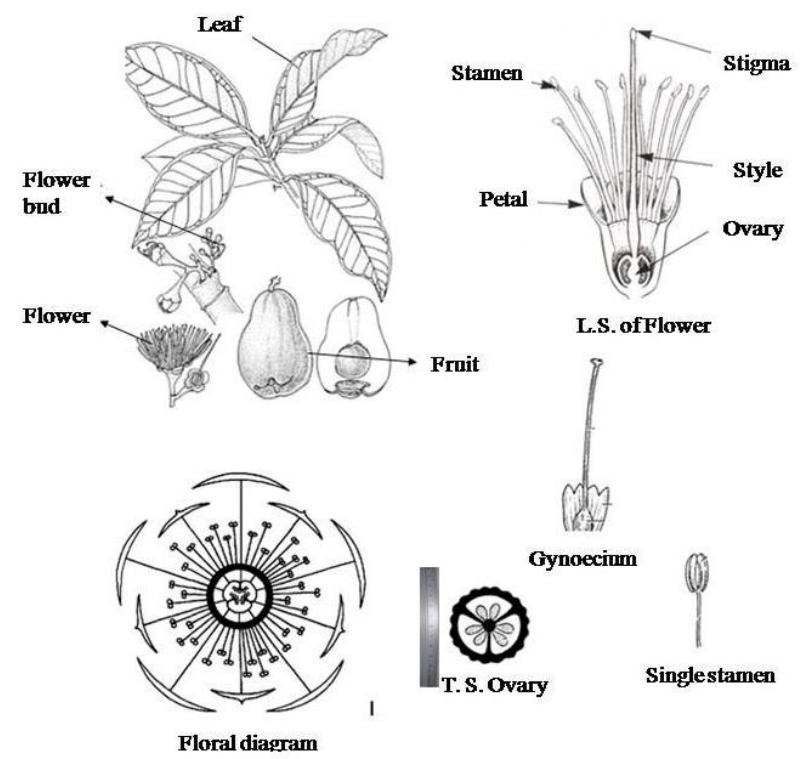

Fig 1. Leaf, flower bud, flower and different part of flower, floral diagram and fruit of wax apple (Syzygium samarangense).

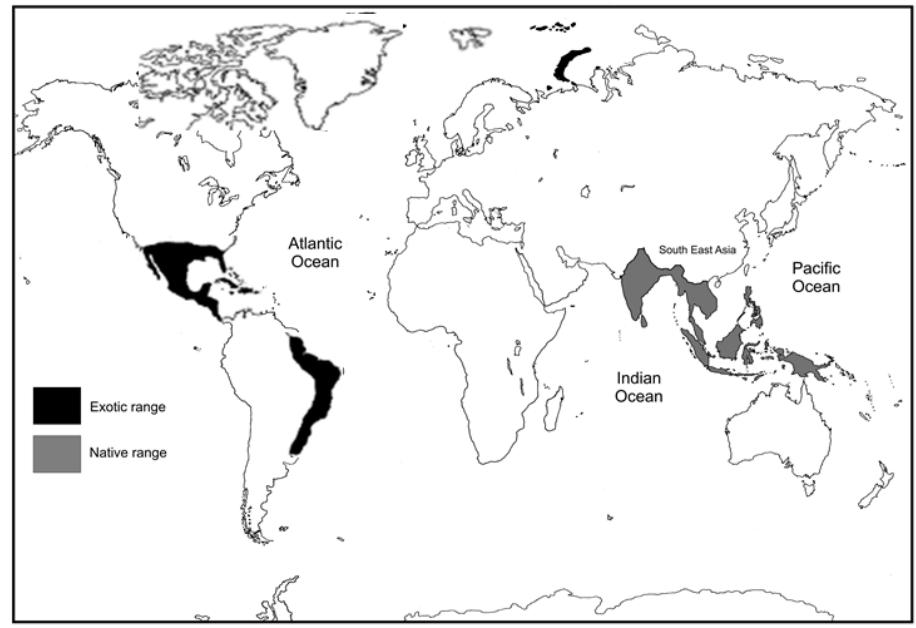

Fig 2. Location of wax apple cultivation in native and exotic range.

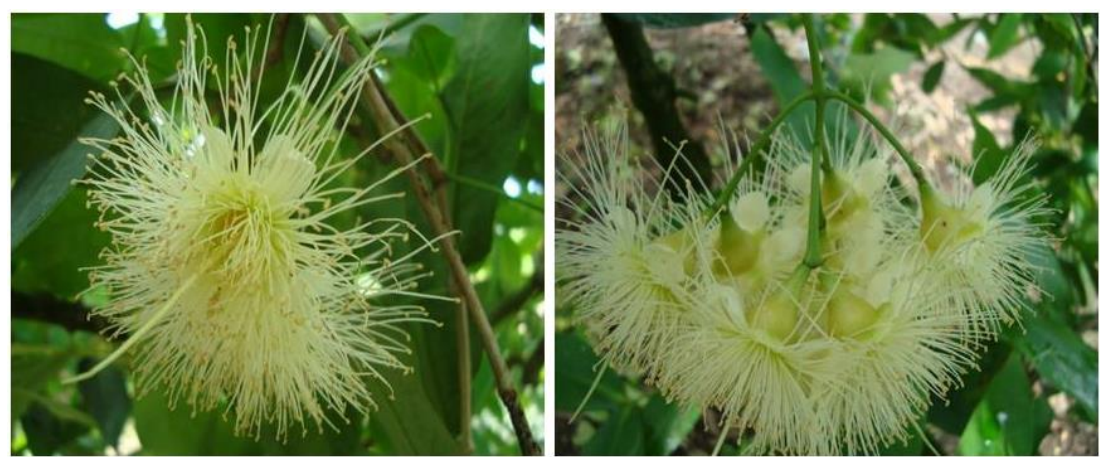

Fig 3. Blooming flower of wax apple (Syzygium samarangense var. Jambu madu red). 

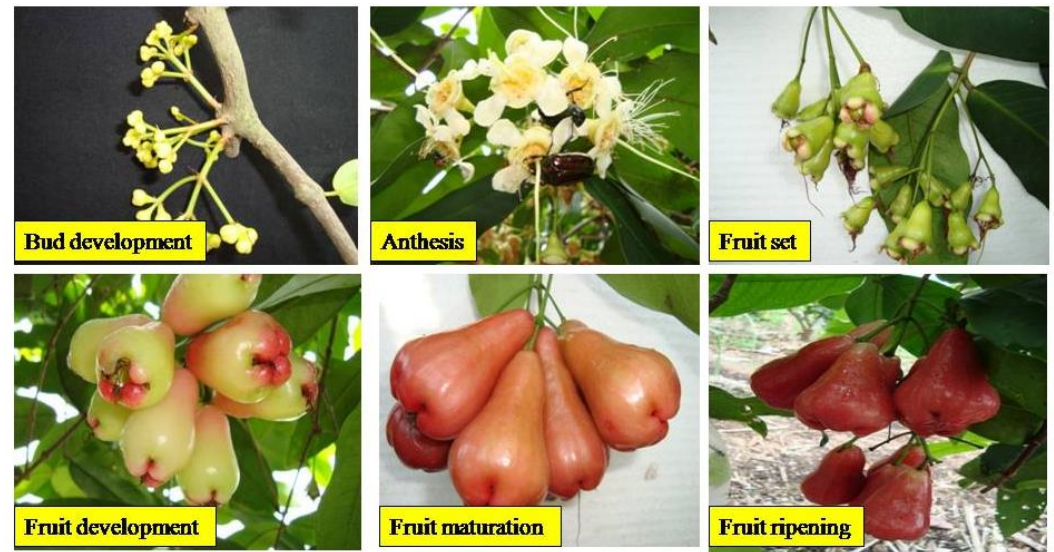

Fig 4. Different stages of fruit growth and development of wax apple (Syzygium samarangense) cultivar: Jambu madu red.

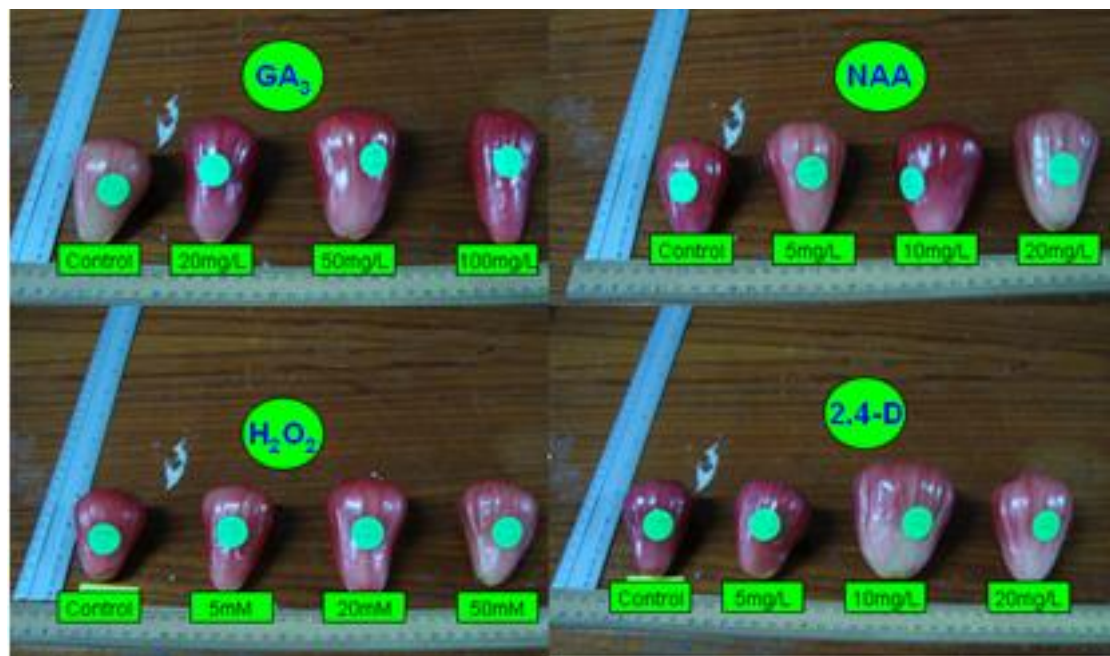

Fig 5. Growth regulators and $\mathrm{H}_{2} \mathrm{O}_{2}$ effects on fruit size of wax apple under tropical conditions.
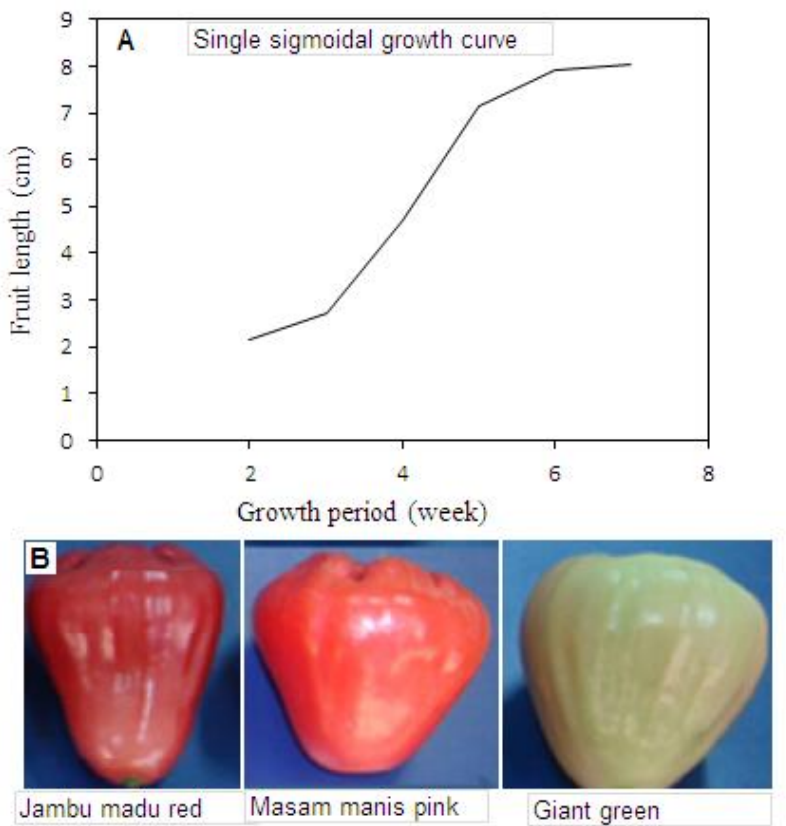

Fig.6. Single sigmoidal growth curve of wax apple (A) and cultivars of Syzygium samarangense (B). 

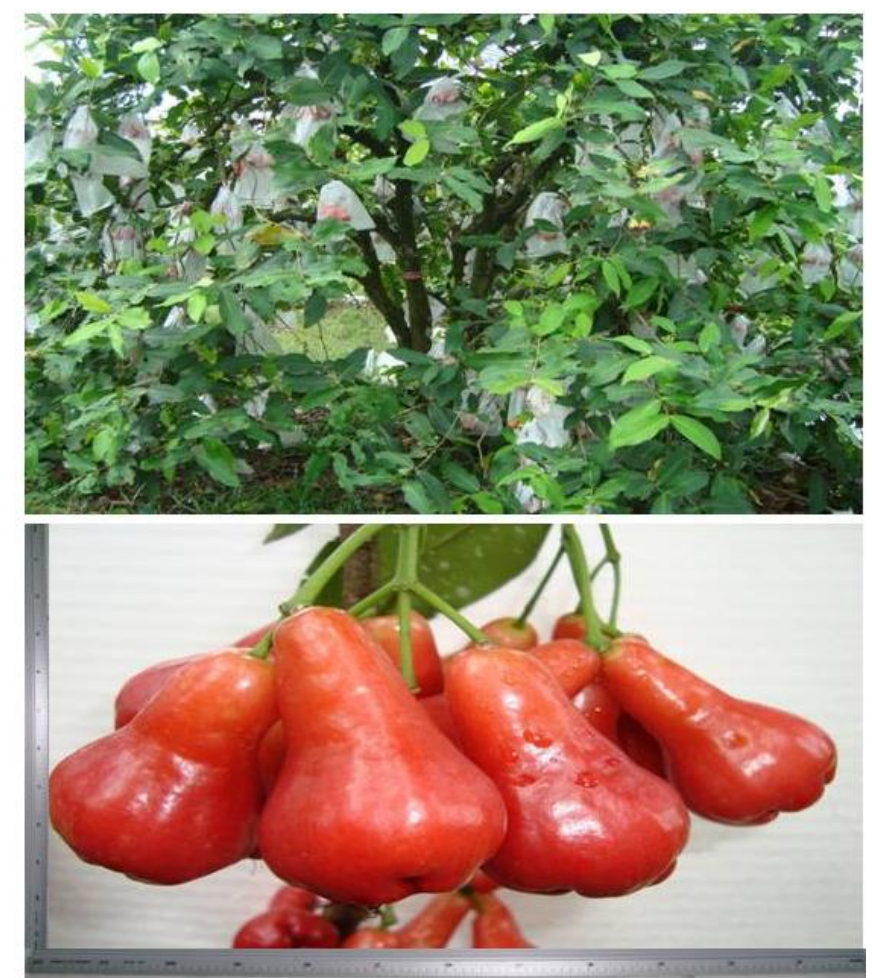

Fig 7. Ripening fruits of wax apple (S. samarangense) cultivar: Jambu madu red.

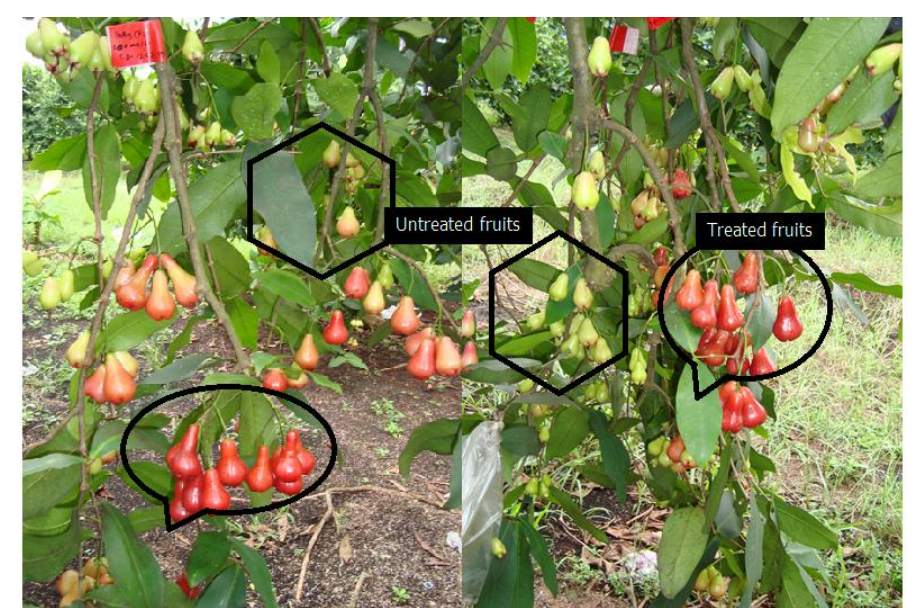

Fig 8. Growth regulators $\left(\mathrm{GA}_{3}\right)$ application stimulates colour development and ripening of wax apple fruits.

al., 2015). Foliar application of $\mathrm{GA}_{3}$ and NAA significantly increased stomatal conductance of wax apple plants (Moneruzzaman et al, 2012). These increased stomatal conductance have positive effects on photosynthesis. Net photosynthetic rate and leaf protein content in wax apple leaves increased notably with doses of NAA and $\mathrm{GA}_{3}$. Sucrose phosphate synthase (SPS), an enzyme important for the synthesis of sucrose in leaves was also affected by NAA treatment. The increased photosynthetic rate of leaves could possibly provide more fructose and glucose 6-phosphate which in turn stimulated sucrose synthesis via sucrose phosphate synthase activity. PGRs treatments may also increase the invertage activity, the increase invertage activity suggests for sucrose synthesis and vice versa due to increased photosynthetic product in treated leaves. It has been reported that NAA and $\mathrm{GA}_{3}$ treatments increased the bud number, fruit set and fruit growth as well final fruit size of wax apple (Fig. 5). May be these increased auxins level in the fruit can promote the sink potential of the fruits, which is in direct proportion of to the rate of fruit growth. During the cell enlargement period, synthetic auxin increases photosynthesis and carbohydrate availability causing cell enlargement and also increase in final fruit size. Auxin may stimulate translocation of carbohydrate to the fruits and increased cell wall elasticity as well as induced fruit growth. The auxins and gibberellins are used during early growth stage of fruits to control the fruit drop in citrus and to improve the quality of fruit. It was also suggested that that rubbing with $50 \mathrm{mg} / \mathrm{L}$ GA3 at inflorescence developing point of phloem once a week from the tiny inflorescence bud until the flower opening resulted in better yield and quality of wax apple fruits (Khandaker et al., 2013). Previous study showed that application of $50 \mathrm{mg} / \mathrm{L} \mathrm{GA} 3,10 \mathrm{mg} / \mathrm{L} \mathrm{NAA}$, and $5 \mathrm{mg} / \mathrm{L} \mathrm{2,}$ 4-D once a week from bud development to fruit maturation increased the physiochemical and phytochemical properties of wax apple fruits (Khandaker et al., 2012b). 
Different types of girdling particularly $\mathrm{C}$ and V-shaped can increase yield and improve nutritional status of the wax apple fruit (Khandaker et al., 2011). Moreover, C-shaped girdling applied two weeks before flowering produced better fruit growth, yield and quality of red wax apple fruits under field conditions (Khandaker et al., 2012a). Girdling or phloemic stress treatment increased the accumulation of carbohydrate content in the upper part of girdle. The increase in carbohydrate level in the leaves a well correlated with the fruit retention. Different girdling treatments especially $\mathrm{C}$ and $\mathrm{V}$-shapes increased the fruit retention and fruit growth of wax apple. The increase in fruit retention with girdling application may be ascribed to increased level of carbohydrates, especially during initial 4-6 weeks of heavy fruitlet abscission. Girdling treatment also increased the $\mathrm{C} / \mathrm{N}$ ratio and carbohydrate content thus reduced the fruitlet abscission and increased the fruit retention of citrus. It was reported earlier that girdling treatment increased the fruit size of wax apple. The increase in fruit size in response to girdling application at the three weeks before flowering may indicate their ability to stimulate carbohydrate translocation to the fruit in combination with their effect on increasing cell wall elasticity.

Hydrogen peroxide $\left(\mathrm{H}_{2} \mathrm{O}_{2}\right)$ plays several versatile roles in normal plant physiological processes and resistance to stresses. It has been regarded as a signaling molecule that can act as a key regulator in a broad range of physiological processes such as senescence, photorespiration and photosynthesis, stomatal movement, cell cycle, growth and development and expression of some genes in plant cells. Application of hydrogen peroxide increased photosynthesis, fruit growth and quality of wax apple under field conditions (Khandaker et al., 2012b). They also reported that $\mathrm{H}_{2} \mathrm{O}_{2}$ is involved in many developmental processes throughout a plant; nevertheless, it can play a major role in fruit set, premature fruit drop and increased total number of wax apple fruits. It was also observed the positive effects of $\mathrm{H}_{2} \mathrm{O}_{2}$ on wax apple yield, total number of fruits, fruit juice and fruit dry matter content. $\mathrm{H}_{2} \mathrm{O}_{2}$ treatments significantly increased the peel colour and anthocyanin content of wax apple fruits, possibly because of an increment in the accumulation of pigment in the skin. It was reported that $\mathrm{H}_{2} \mathrm{O}_{2}$ may be responsible for the improvement of antioxidant status of fruits by activating gene expression of PAL, CHS and stylbene synthase. $\mathrm{H}_{2} \mathrm{O}_{2}$ treatment improved the physiological and biochemical properties of the wax apple fruits and did not decrease plant growth or fruit productivity (Khandaker et al , 2012b).

\section{Fruit maturation and harvest}

Fruit growth and development involves changes in its morphology, anatomy and physiology (Chahidi et al., 2008) whilst fruit ripening is associated with dramatic changes in rind texture, color, juice composition, increase in softness due to changes in the cell walls, the metabolism of organic acids and the development of compounds involved in flavor and taste (Davies et al., 1997; Javanmardi and Kubota, 2006). The number of days from bloom to the time for harvest is a useful guide to determine the harvest time where the shape, ground color, size or sheen on the fruit are usually as indicators of maturity.

There are definite flowering seasons, often two, sometimes three in a year, in spring, summer and fall. The biggest crops are produced in the spring and fall flowering seasons. The tree flowers in May and June and the fruits ripen in August and September and the second crop is often in November and
December. Wax apple commonly flower early or late in the dry season; the flowers appear to be self-compatible and the fruit ripens around 30-40 days after anthesis (Morton, 1987). There are three common types of growth patterns among different fruits including a single (Fig. 6), double, or triple sigmoidal curve for growth (Coombe, 1976; Trimble et al., 2006). Many fruits, such as apple (Dennis, 1986) and banana (Israeli and Lahav, 1986) are reported to have a single sigmoidal growth curve in which there is an initial phase of slow growth, followed by a rapid growth period, and finally a period of declining growth rate when ripening is often initiated.

Other fruits including stone fruits, figs, and grapes show a double sigmoid curve in which there are two rapid growth phases (respectively named as periods I and III) interrupted by one short period of growth, namely period II. The growth pattern of the kiwifruit (Actinidia chinensis) can be described as triple sigmoidal (Bollard, 1970). Normally, the fruit is harvested when blossom-end is fully expanded and skin shows desired market colour. The fruit size can be as small as about $4.3 \mathrm{~cm}$ long and $4.7 \mathrm{~cm}$ wide to more than $5.2 \mathrm{~cm}$ long and $5.0 \mathrm{~cm}$ wide (bell-shaped) or 7 to $8 \mathrm{~cm}$ long and $4 \mathrm{~cm}$ wide (elongated) (Fig. .5). According to Shao et al. (1998), the growth of jambu fruits exhibits a sigmoidal growth curve. Fruit mass ranges from $28 \mathrm{~g}$ to $100 \mathrm{~g}$ and fruit sized of more than $200 \mathrm{~g}$ per fruit (Shu et al., 2007). Fruit shape ranges from round to bell shaped, oval or elongated and skin color diverges from white to pale green to dark green, pink to red to deep red (Fig. 3 \& 6). Wax apple trees are tropical preferring temperature above $18^{\circ} \mathrm{C}$ and cannot tolerate temperatures below $7^{\circ} \mathrm{C}$, (Hung et al., 2005). Fruits of wax apple prefer warm temperatures for normal growth and development. Low temperatures impede fruit growth and red color development, while high temperatures accelerate fruit growth and ripening yet inhibit red color development. The fruits have a thin red skin and are delicate (Fig 3); they need to be picked by hand twice a week and handled with care. The fruit should be consumed or preserved within a few days from harvest.

\section{Ripening of wax apple}

It is a non-climacteric fruit according to (Akamine and Goo, 1979). It has been found that wax apple have a very low respiration rate of $10-20 \mathrm{mg} \mathrm{CO} / \mathrm{kg}$. h at $20^{\circ} \mathrm{C}$, although they are highly perishable fruits (Akamine and Goo, 1979).

Without any preformed injuries, the sound fruit shows a good keeping quality at 2 to $5^{\circ} \mathrm{C}$ and at 2 to $10^{\circ} \mathrm{C}$ wax apple produce very low ethylene. However, chilling injury is a problem at these temperatures. Storage at 12 to $14^{\circ} \mathrm{C}$ (54 to $57^{\circ} \mathrm{F}$ ) with 90 to $95 \% \mathrm{RH}$ would result in a shelf-life of 10 to 14 days. Fruit peel color of the most popular cultivar in Taiwan, 'Pink', ranges from light-red to deep-red despite of its name, besides the pulp color white creamy to light red (Fig. 7). As more is paid for the deep-colored fruits, factors influencing red color of 'Pink' has attracted much interest. At present, not only does intact wax apple fruit is an important fruit in the markets but fresh-cut wax apple has also become a popular fresh-cut product, especially in Southeast Asia (Worakeeratikul et al., 2007). It has been reported that red color of wax apple is influenced by such factors as: leaf: fruit ratio (Wang, 1991), sugars (Liaw et al., 1999; Shu et al., 2001), position of fruits on the tree (Shu, 1999), fruit development stages (Chan et al., 2003) light and temperature Shu et al., 2001). The crucial timing for sugar availability (or optimum developmental stages for sucrose utilization) for the development of wax apple fruits especially anthocyanin in 
fruit skin is not known (Chan et al., 2003). Growth regulators $\left(\mathrm{GA}_{3}\right.$ and NAA) and growth regulating chemicals $\left(\mathrm{H}_{2} \mathrm{O}_{2}\right)$ significantly influence the ripening process of wax apple fruits and promote the colour development of wax apple (Fig. 8). $\mathrm{H}_{2} \mathrm{O}_{2}$ treatments significantly increased the peel colour of wax apple fruits in this study, possibly because of an increment in the accumulation of pigment in the skin and increased the PAL activity. Some other research also reported that $\mathrm{H}_{2} \mathrm{O}_{2}$ treatments of cantaloupe and honey dew melons significantly improved colour, general appearance and shelf life. It has been reported earlier that girdling treatment also significantly affects the color development and fruit quality.

\section{Functional uses of wax apple}

The ripe, pink fruits of wax apple are bell-shaped, sweet and can be eaten fresh or cooked, for sauces, jams, jellies desserts, wines, liquors, and vinegars. In Malaysia, the green fruits of wax apple are eaten raw with salt or cooked as a sauce. Some volatile constituents, such as 2-phenylethanol and its derivatives, were found to be the major compounds in the fruit (Pino et al., 2004). This plant has also been reported as a good xanthine oxidase (Guerrero and Guzman, 1998) and an aldose reductase inhibitor (Guzman and Guerrero, 2005). The whole plant has a variety of medicinal uses which range from dermatological, digestive, head and throat to endocrine remedy. In Malaysia, powder from the dried leaves is applied on cracked tongue, while a preparation of the roots is used to cure itching, given to alleviate swelling, to treat dysentery and serves as an emmenagogue and abortifacient (Brown et al., 1988).

The fruits of $S$. samarangense are also have several medicinal properties. In Taiwan, people make wax apple soup with crystal sugar to treat coughing without phlegm. The fruit is also served as a cold dish on banquets to relieve the effects of alcohol. The flowers, which contain tannins, desmethoxymatteucinol, 5-O-methyl-40-desmethoxymatteucinol, oleanic acid, and b-sitosterol, are used in Taiwan to treat fever and halt diarrhea (Morton, 1987). In addition to their use as food; many of these fruits have been used in divergent traditional medical practices for a variety of illnesses and conditions. Most notably, the seeds of the jamun (S. cumini) are an important ayurvedic medicine for diabetes. The rose apple ( $S$. jambos) has been used in India as a tonic for the brain and for liver problems, as an astringent, and digestive (Kirtikar and Basu, 1988), and distilled to make rosewater (Morton, 1987). Other related Myrtoideae fruits can be used for several inflammatory conditions, including sore throat, high blood pressure, ringworm, and as an antimicrobial, antiscorbutic, carminative, diuretic, and astringent (Rivera and Obon, 1995). Ethanolic leaf extract of wax apple has been reported to exhibit immuno stimulant activity (Srivastava and Shaw, 1985), while the hexane extract was found to relax the hyper motility of the gut (Ghayur et al., 2006) . The alcoholic extract of the stem bark has shown antibacterial activity (Chattopadhayay et el., 1998). In Brazil, Eugenia brasiliensis leaves have been used for gastrointestinal disorders and rheumatism (Morton, 1987), and the jaboticaba fruit (Malpighia cauliflora) has been used as a treatment for hemoptysis, asthma, diarrhea, and chronic inflammation of the tonsils. Syzygium jambolanum is well known Indian folk medicine for treatment of diabetes mellitus and heat antidiabetic potential of the fruits and seed extracts (Samba-Murthy and Subrahmanyam, 1989). Methanol leaf extract of Syzygium Jambolanum has insulinlike properties and may be useful as potential therapeutic agent in the management of hyperglycemia (Lim et al.,
2008). It was reported earlier that 'Jambu Madu Red' and 'Masam Manis Pink' cultivars are comparatively better yield than those of 'Giant Green' cultivar grown under tropical field conditions (Khandaker et al., 2015a). Our previous study has shown that wax apple cultivars are ultimate source of bioactive constituents, trace elements and metabolites that have the potential to serve as antioxidant and antibacterial compounds beneficial for human health and may serve as a lead to the development of new pharmaceutical products (Moneruzzaman et al., 2015; Moneruzzaman et al., 2011a; Moneruzzaman et al., 2012b).

\section{Conclusion}

Judging from the literature discussed above, it is apparent that wax apple is a very important non-climacteric tropical fruit. Wax apple fruits follow the single sigmoidal growth patterns. The fruit growth, ripening and quality of wax apple can be improved by applying plant $\mathrm{GA}_{3}$, NAA, C-shaped girdling and $\mathrm{H}_{2} \mathrm{O}_{2}$ during early fruit developmental stages. Jambu madu red and Masam manis pink cultivars contain the highest fruit quality in September to November growing seasons in case of tropical climate. The fruit and other plant parts can be used for several medicinal purposes, antimicrobial and antioxidant agent and to cure diabetes and skin problem in our daily life.

\section{Acknowledgements}

This research was supported by University of Malaya, 50603, Kuala Lumpur, Malaysia and Universiti Sultan Zainal Abidin, Besut Campus, 22200 Besut, Terengganu.

\section{Reference}

Adel AS, Hossain ABMS, Taha RM, Moneruzzaman KM (2011) Photosynthetic yield, fruit ripening and quality characteristics of cultivars of Syzygium samarangense. Afr J Agril Res. 6 (15): 3623-3630.

Akamine EK, Goo T (1979) Respiration and ethylene production in fruits of species and cultivars of Psidium and species of Eugenia. J Amer Soc Hort Sci. 98: 381-383.

Amor EC, Villasenor IM, Ghayur MN, Gilan AH, Choudhary MI (2005) Spasmolytic flavonoids from Syzygium samarangense (Blume) Merr. \& L. M. Perry. Z Naturforsch C. 60(1-2): 67-71.

Bollard EG (1970) The physiology and nutrition of developing fruits. In the biochemistry of fruits and their products. (Ed. Hulme, A.C).pp.387-425. Academic press: London

Brown K, Jackson DI, Steans GF (1988) Effects of chlormequat, girdling, and tipping on berry set in Vitis vinifera L. J Amer Enol Viticult. 39: 91-94.

Chang YJ, Chung MY, Tseng MN, Chu CC, Shu ZH (2003) Developmental stages affect characteristics of wax apple fruit skin discs cultured with sucrose-with special reference to color. Sci Hort. 98(4): 397-407.

Chattopadhayay ED, Sinha BK, Vaid LK (1998) Antibacterial activity of Syzygium species. Fitoterapia. 119(4): 365-367.

Chandrasekaran M, Vankatesalu V (2004) Antibacterial and antifungal activities of Syzygium jambolanum seeds, J. Ethnopharmacol. 91(1): 105 -108.

Chahidi B, El-Otmani M, Luro F, Srairi I, Tijane M (2008) Changes of fruit quality traits in 7 clementine selections during maturation. Electronic J Environ Agril Food Chem. 7(1): 2565-2577. 
Coombe BG (1976). The development of fleshy fruits. Ann Rev Plant Physiol. 27: 507528.

Davies C, Boss PK, Robinson SP (1997) Treatment of grape berries, a nonclimacteric fruit with a synthetic auxin, retards ripening and alters the expression of developmentally regulated genes. Plant Physiol. 115(3): 1155-1161.

Dennis FG (1986) Apple. Handbook of Fruit Set and Development: pp.1-44. CRC Press, Boca Raton, Florida, USA.

FAO (2005) Growing pains for tropical fruit market. Rome: Food and Agricultural Organization of the United Nations. Available from: <www.fao.org/NEWS/1998/ 980604E.HTM>. Accessed October 19th, 2005.

Ghayur MN, Gilani AH, Khan A, Amor EC, Villasenor IM, Choudhary MI (2006) Presence of calcium antagonist activity explains the use of Syzygium samarangense in diarrhea. Phytotherapy Res. 20(1): 49-52.

Guerrero RO, Guzman AL (1998) Inhibition of xanthine oxidase by Puerto Rican plant extracts. P R Health Sci J. 17:359-6.

Guzman A, Guerrero RO (2005) Inhibition of aldose reductase by herbs extracts and natural subtances and their role in prevention of cataracts. Revista Cubana Plantas Medicinales. 10:3- 4.

Gurib-Fakim A (2006) Medicinal plants: traditions of yesterday and drugs of tomorrow. Mol Aspects Med. 27(1), $1-93$.

Guardiola JL (1992) Fruit set and growth. In: Donadio LC (ed) Second International Seminar on Citrus. Univ of Bebedouro, pp 1-30

Hakim AS, Panggabean H (1992) The tertiary volcanic belts of the west Pacific margin, northeastern Indonesia. J Southeastern Asian. 7: 258-262.

Hung SH, Yu CW, Lin CH (2005) Hydrogen peroxide function as a stress signal in plants. Bot Bull Acad Sin. 46: $1-10$.

Israeli Y, Lahav E (1986) Banana. CRC Handbook of Fruit Set and Development: 45-73.

Javanmardi J, Kubota C (2006) Variation of lycopene, antioxidant activity, total soluble solids and weight loss of tomato during postharvest storage. Postharvest Biol Technol. 41(2): 151-155.

Khandaker MM, S Hossain ABM, Osman N, Boyce AN (2011) Application of girdling for improved fruit retention, yield and fruit quality in Syzygium samarangense under field conditions. Int J Agril Biol. 13: 18-24.

Khandaker MM, Sharif Hossain ABM, Osman N, Mat N, Amru Nasrulhaq B (2015b) Growth, Yield and Postharvest quality of Wax Apple as Affected by Naphthalene Acetic Acid Application. Rev Brasil Frut. 37 (2): 410-422.

Khandaker KM, Normaniza O, Hossain ABMS, Boyce AN (2012a) The effect of the phloemic stress on the growth, development and quality of wax Jambu (Syzygium samarangense) var. Jambu madu. Sains Malay. 41 (5):553560.

Khandaker KM, Normaniza O, Boyce AN (2012b) The influence of hydrogen peroxide on the growth, development and quality of wax apple (Syzygium samarangense, var. jambu madu) fruits. Plant Physiol Biochem. 53:101-110.

Khandaker KM, Normaniza O, Boyce AN, Faruq G, Motior Rahman M, Sofian-Azirun M (2013) Fruit development, pigmentation and biochemical properties of wax apple as affected by localized application of GA3. Brazil Arch Biol Technol. 56(1):11-20.
Khandaker MM, Alebidi AI, Sarwar J Md, B Amru Nasrulhaq (2015a) Physiological and biochemical properties of three cultivars of wax apple (Syzygium samarangense [Blume] Merrill \& L.M. Perry) fruits. J Sus Sci Manag. 10(1): 66-75.

Kirtikar KR, Basu BD (1988) Indian Medicinal Plants. Dehradun: International Book Distributors.

Kuo YC, Yang LM, Lin LC (2004) Isolation and immunomodulatory effects of flavonoids from Syzygium samarangense, Planta Med. 70(12): 1237-1239.

Liaw SC, Shu ZH, Lin HL, Lee KC (1999) Effects of sugars on anthocyanin biosynthesis in wax apple fruit skin (in Chinese). J Agril Assn China.185: 72-80.

Lim SL, Chai JW, Kuppusamy UR (2008) Evaluation of Syzygium jambolanum methanolic leaf extract for insulinlike properties. Res J Biol Sci. 3(9): 1109-1114.

Morton JF (1987) Fruits of Warm Climates. Miami, Florida. pp. 381-382.

Moneruzzaman KM, Alebidi AI, Al-Saif AM (2012a) Assessment of genetic diversity in three cultivars of Syzygium samarangense grown in Malaysia by using morphological and physiological parameters. Res J Biotechnol. 7(3):16-22.

Moneruzzaman KM, Jahan SM, Nashriyah M, Nasrulhaq BA (2015) Bioactive constituents, antioxidant and antimicrobial activities of three cultivars of wax apple (Syzygium samarangense L.) fruits. Res J Biotechnol. 10 (1):1-10.

Moneruzzaman KM, Hossain ABMS, Normaniza O, Boyce AN (2011a) Growth, yield and quality responses to $\mathrm{GA}_{3}$ of wax apple Syzygium samarangense. Afr J Biotechnol. 10 (56):11911-11918.

Moneruzzaman KM, Boyce AN, Normaniza O, Hossain ABMS (2012b) Physiochemical and phytochemical properties of wax apple (Syzygium samarangense [Blume] Merrill \& L.M. Perry) as affected by growth regulator application under field conditions. Sci World J. volume 2012, Article ID 728613.

Moneruzzaman KM, Al-Saif AM, Alebedi AI, Hossain ABM, Normaniza O. and Boyce AN (2011b) Nutritional quality evaluation of three cultivars of Syzygium samarangense under Malaysian conditions. Afr J Agril Res. 6 (3):545-552.

Neergheen VS, Soobrattee MA, Bahorun T, Aruoma OI (2006) Characterization of the phenolic constituents in Mauritian endemic plants as determinants of their antioxidant activitiesin vitro, J Plant Physiol. 163(8): 787799.

Nakasone HY, Paull RE (1998) Tropical Fruits. CAB International, New York. p.400

Pino JA, Marbot R, Rosado A, Vázquez C (2004) Volatile constituents of Malay rose apple [Syzygium malaccense (L.) Merr. \& Perry]. Flavour and Fragrance J. 19: 32-35.

Resurreccion-Magno MH, Villasenor IM, Harada N, Monde K (2005) Antihyperglycaemic flavonoids from Syzygium samarangense (Blume) merr. and perry, Phytotherapy Res. 19(3): $246-251$

Shao LH, Deng L, Qing LY (1998) Effects of floral promotion or inhibition treatments on flowering of citrus trees and protein fraction in buds. J Trop Subtrop Bot. 6: 124-130.

Shu ZH, Tzong SL, Jung ML, Chi CH, Der NW, Hsiao HP (2007) The industry and progress review on the cultivation and Physiology of Wax apple-with special reference to pink variety. Asian Aus J Plant Sci Biotechnol. @Global Science Books 
Shafi PM, Rosamma MK, Jakil K, Reddy PS (2002) Antibacterial activity of Syzygium cumuni and $S$. travancoricum leaf essential oils. Fitoterapia, 73(5): 414416.

Rivera D, Obón C (1995) The ethno pharmacology of Madeira and Porto Santo islands, a review. J Ethnopharmacol. 46:73-93.

Samba-Murthy AV, Subrahmanyam NS (1989) Fruits. In: A text book of economic botany, Wiley, New Delhi, India, pp: 629 .

Srivastava R, Shaw AK (1995) Kulshreshtha Triterpenoids and chalcone from Syzygium samarangense, Phytochem. 38(3): 687-689.

Shu ZH (1999) Position on the tree affects fruit quality of Bald-cut wax apples. J Appl Hort. 1 (1):15-18.

Shu ZH, Wang DN, Sheen TF (1996) Wax apple as a potential economic crop for the world. In: Vijaysegaran, S., Pauziah, M., Mohamed, M. S., Ahmad Tarmizi, S. (Eds.), Proceedings of the International Conference Tropical Fruits, vol. I. Malaysian Agr. Res. Dev. Inst., Serdang, Selangor, Malaysia, pp. 69-73.

Shu ZH, Chu CC, Hwang L J, Shieh, CS (2001) Light, temperature and sucrose affect color, diameter and soluble solids of disks of wax apple fruit skin. Hort Sci. 36: 279281.

Trimble V, Aschwanden MJ, CJ Hansen (2006) Astrophysics in 2005. Publications of the Astrono. Soc. Pacific 118(845): 947-1047.
Wang DN (1991) Past, present and future of wax apple production in Taiwan (in Chinese). In: Yang, C.R. (Ed.), Proceedings of the Symposium Fruit Production, Research and Development in Taiwan. Chia-Yi Agr. Expt. Sta., Taiwan Agr. Res. Inst., Taiwan, pp.339-355.

Wong KC, Lai FY (1996) Volatile constituents from the fruits of four Syzygium species grown in Malaysia. Flavour Frag J. 11(1): 61-66.

Worakeeratikul W, Srilaong V, Uthairatanakij A, Jitareerat P (2007) Effects of whey protein concentrate on quality and biochemical changes in fresh-cut rose apple. Acta Hort. 746: 435441.

Whistler WA, Craig RE (2006) Syzygium malaccense (Malay apple), Myrtaceae (myrtle family). Species profiles for Pacific Island agroforestry. Retrieved on February, 2007 from www.traditionaltree.org.

Verheij EWM, Coronel R (1991) Plant resources of SouthEast Asia, Vol. 2: Edible fruits and nuts. PUDOC, Wageningen, The Netherlands, pp. 446.

Young JF (1951) Fruits in Taiwan (in Chinese). Chia-Yi Agr. Expt. Sta., Chia-Yi., Taiwan, Research and Development in Taiwan. Chia-Yi Agr. Expt. Sta., Taiwan Agr. Res. Inst., Taiwan, pp. 339-355.

Zen-hong S, Meon Z, Tirtawinata R, Thanarut C (2006) Wax apple production in selected tropical Asian countries. ISHS. Acta Hort. 773: 161-164. 